\title{
Auditory Deprivation Caused By Early Otitis Media with Effusion
} \author{
Macangnin Seimetz ${ }^{4}$ and Sady Selaimen da Costa ${ }^{5}$ \\ ${ }^{1}$ Department of Speech Pathology, Federal University of Health Sciences of Porto Alegre, Brazil \\ ${ }^{2}$ Department of Health and Human Communication, Federal University of Rio Grande do Sul, Brazil \\ ${ }^{3}$ Speech Therapist, M.S. in Child and Adolescent Health at the Federal University of Rio Grande do Sul, Brazil \\ ${ }^{4}$ Speech Therapist, M.S. in Child and Adolescent Health at the Federal University of Rio Grande do Sul, Brasil
}

Marcia Salgado Machado*1, Adriane Ribeiro Teixeira ${ }^{2}$, Andressa Colares da Costa Otavio ${ }^{3}$, Bruna

${ }^{5}$ Department of Ophthalmology and Otorhinolaryngology, Federal University of Rio Grande do Sul, Brazil

Received: May 25, 2018; Published: June 01, 2018

*Corresponding author: Marcia Salgado Machado, Speech therapist, Ph.D, Graduate Program in Child and Adolescent Health of the Federal University of Rio Grande do Sul, Assistant Professor, Department of Speech Pathology, Federal University of Health Sciences of Porto Alegre, 245. Brazil

\begin{abstract}
Introduction: In the past 40 years, the literature has attempted to clarify the evidence on the effect of early auditory deprivation caused by early otitis media with effusion (OME) on central auditory processing (CAP). Objective: The aim of this study was to evaluate the scientific evidence on the effects of auditory deprivation caused by early OME on the CAP of children and adolescents. Data Synthesis: A systematic search was conducted in the following databases: Scientific Electronic Library Online (Scielo), Latin American and Caribbean Health Sciences (Literatura Latino-Americana e do Caribe em Ciências da Saúde-LILACS), PubMed, Scopus, and Web of Science, PubMed, Medline, and Cochrane databases from the earliest publication, up until October 2016. Prospective studies that reported children or adolescents (aged less than 18 years) with early OME in the first years of life. Conclusions: We selected eight studies on the research topic. The results indicated a correlation between auditory deprivation caused by early OME and changes in CAP in children and adolescents. The hearing ability that was consistently susceptible to auditory deprivation was the auditory figure-ground.
\end{abstract}

Keywords: Auditory Perception; Otitis Media; Children

\section{Introduction}

Otitis media with effusion (OME) is a middle-ear inflammation characterized by the presence of fluid in the middle ear without signs or symptoms of acute infection and perforation of the tympanic membrane [1]. This condition reduces the mobility of the tympanic membrane and limits the transmission of sound waves [2]. The high prevalence of OME in early childhood has generated speculation about its effect on the development of the human auditory system because this condition is the most common reason for medical consultations and surgeries in children 3 . When it affects children in the first five years of life, it can be considered "early" $[3,4]$. It is believed that temporary and fluctuating hearing loss caused by the disease at this stage of life may impair hearing development [3-5] and is considered a form of auditory deprivation [6].

The first study that described a probable association between early auditory deprivation and changes in auditory development in the long term dates from 1962. This case report described the effects of auditory deprivation on the late behavior of a patient [7]. Since then, several studies [3-6,8-13] have attempted to elucidate the effect of early auditory deprivation caused by early OME on central auditory processing (CAP) in the long term. However, despite the large number of studies published in the past 40 years, many controversies persist $[13,14]$. These controversies are criticized by several authors because most of these studies were retrospective $[3,5,15,16]$ which limited the establishment of a precise correlation between the disease and outcomes 3 . Therefore, longitudinal studies are needed to see if the negative effects of early OME persist after the recovery of tonal auditory thresholds [16]. The aim of this study was to analyze the scientific evidence on the effects of auditory deprivation caused by early OME on the CAP of children and adolescents. Therefore, this study was developed by the following questions:

a) The association between hearing deprivation caused by early OME and changes in the CAP in children and adolescents; 
b) The auditory skills of CAP that are susceptible to auditory deprivation caused by early OME.

\section{Review of Literature}

This systematic review involved the search of studies on the effect of early OME on the CAP of children and adolescents. Systematic reviews are used as a starting point for the conduct of clinical practice and thus are crucial in health care [17]. The planning and development of this study were based on the guidelines of the Preferred Reporting Items for Systematic Reviews and Meta-Analyses (PRISMA) [17]. The search was conducted in the following databases: Scientific Electronic Library Online (Scielo), Latin American and Caribbean Health Sciences (Literatura Latino-Americana e do Caribe em Ciências da Saude-LILACS), PubMed, Scopus, and Web of Science. The descriptors were searched using the structured and trilingual "Descriptors in Health Sciences" (Descritores em Ciências da Saude-DeCS), prepared by the Latin American and Caribbean Center of Information in Health Sciences (Centro Latino-Americano e do Caribe de Informacoes em Ciências da Saude) from the Regional Library of Medicine (Biblioteca Regional de Medicina-BIREME) for use in the indexing of articles from scientific journals, books, conference proceedings, technical reports, and other materials.

\section{The Search Strategy Was Performed With the Following} Descriptors

"Auditory perception" OR "Auditory perceptual disorders" OR "Auditory diseases, central" AND "Otitis media." There was no restriction of the initial date for the search of the articles and, therefore, the selection period involved all articles published until October 2016 .

\section{The Following Inclusion Criteria Were Adopted}

Studies that evaluated children or adolescents (aged less than 18 years) with early OME; studies with a prospective design about

Table 1: Characteristics of the studies included in this review. to the monitoring of early OME and recommendation grade of at least B [18]; studies with detailed descriptions of the criteria used for the diagnosis of otitis media in the subjects investigated; studies that described the evaluation procedures and interpretation criteria of the auditory processing tests used; and studies published in English, Portuguese, and Spanish. The studies that did not agree with the inclusion criteria and those that did not present the data clearly were excluded from the selection process. The studies were selected from August to October 2016. The studies were selected by two independent researchers and subsequently analyzed by a third professional (judge), who analyzed whether the articles selected were in accordance with the established criteria.

\section{Results}

(Figures 1) \& (Table 1) the results observed in the selected studies will be presented according to the assessed auditory ability. In the auditory figure-ground, three studies $[5,15,19]$ that used tests for their evaluation verified changes. Only one of the studies 6 showed no evidence of changes in this ability. Furthermore, the study by Hogan and Moore [3] found changes only in children with very persistent OME. The binaural hearing was investigated in cases of asymmetric OME, but no alterations were found in the study sample [10]. One study 3 found alteration in this ability only in children with very persistent OME ( $>45 \%$ ), two studies found no evidence of deficit in this aspect $[19,20]$. The auditory temporal resolution was evaluated in a single study included in this review [4], wherein this ability was recovered after normalization of the hearing thresholds changed by OME. Other hearing abilities were less emphasized in the selected studies, including binaural integration and auditory closure. Only one study evaluated these abilities [19] and indicated no changes in the comparison of the group with and without early OME. In addition to these abilities, Gravel et al. [6] evaluated sound localization and found no changes in the study sample.

\begin{tabular}{|c|c|c|c|c|c|c|c|c|}
\hline $\begin{array}{c}\text { Authors } \\
\text { and year of } \\
\text { publication }\end{array}$ & Country & Objective & $\begin{array}{c}\text { Study } \\
\text { sample }\end{array}$ & & $\begin{array}{l}\text { Diagnosis of } \\
\text { early OME }\end{array}$ & & CAP tests & $\begin{array}{c}\text { Assessed } \\
\text { hearing } \\
\text { abilities }\end{array}$ \\
\hline & & & $\mathbf{n}$ & $\begin{array}{c}\text { Average age } \\
\text { (years) }\end{array}$ & Procedures & Criteria & & \\
\hline $\begin{array}{c}\text { Gravel and } \\
\text { Wallace [15] }\end{array}$ & United States & $\begin{array}{l}\text { Examine a cohort of } \\
\text { preschool children } \\
\text { whose middle ear } \\
\text { conditions were } \\
\text { properly documented } \\
\text { during the first year of } \\
\text { life. }\end{array}$ & 23 & 4,1 & $\begin{array}{c}\text { Periodic } \\
\text { otoscopy during } \\
\text { the first year of } \\
\text { life. }\end{array}$ & $\begin{array}{l}\text { Presence of } \\
\text { effusion in the } \\
\text { bilateral middle } \\
\text { ear in } 30 \% \text { of } \\
\text { the evaluations. }\end{array}$ & $\begin{array}{l}\text { Adaptive } \\
\text { PSI }\end{array}$ & $\begin{array}{l}\text { Auditory } \\
\text { figure- } \\
\text { ground. }\end{array}$ \\
\hline $\begin{array}{l}\text { Hutchings et } \\
\text { al. [20] }\end{array}$ & UK & $\begin{array}{l}\text { Evaluate the MLD in } \\
\text { infants, children, and } \\
\text { adults with normal } \\
\text { hearing and compare } \\
\text { these results with } \\
\text { MLD of infants with } \\
\text { documented OME. }\end{array}$ & 37 & $\begin{array}{c}\text { 0,58 (infants). } \\
9,5 \text { (children) } \\
23,9 \text { (adults) }\end{array}$ & $\begin{array}{c}\text { Otoscopy and } \\
\text { tympanometry } \\
\text { monthly home } \\
\text { visits initiated } 4 \\
\text { to } 7 \text { weeks after } \\
\text { birth. }\end{array}$ & $\begin{array}{l}\text { Type B } \\
\text { tympanogram } \\
\text { (at least } 3 \\
\text { evaluations). }\end{array}$ & MLD & $\begin{array}{l}\text { Binaural } \\
\text { integration. }\end{array}$ \\
\hline
\end{tabular}




\begin{tabular}{|c|c|c|c|c|c|c|c|c|}
\hline $\begin{array}{l}\text { Schilder et } \\
\text { al. [19] }\end{array}$ & Netherlands & $\begin{array}{l}\text { Evaluate the effect } \\
\text { of OME in preschool } \\
\text { children on auditory } \\
\text { perception in school age. }\end{array}$ & 89 & 8,02 & $\begin{array}{l}\text { Tympanometry } \\
\text { every } 3 \text { months } \\
\text { during screening } \\
\text { for OME at ages } \\
2 \text { to } 4 \text { years. }\end{array}$ & $\begin{array}{c}\text { Type B } \\
\text { tympanogram } \\
\text { on either ear. }\end{array}$ & $\begin{array}{l}\text { SNT } \\
\text { FST } \\
\text { BFT } \\
\text { DLT }\end{array}$ & $\begin{array}{c}\text { Binaural } \\
\text { integration, } \\
\text { binaural } \\
\text { interaction, } \\
\text { auditory } \\
\text { closure, } \\
\text { auditory } \\
\text { figure- } \\
\text { ground. }\end{array}$ \\
\hline $\begin{array}{l}\text { Stoolman et } \\
\text { al. [10] }\end{array}$ & Netherlands & $\begin{array}{l}\text { Assess the possible } \\
\text { effects of early } \\
\text { asymmetric OME on } \\
\text { binaural hearing. }\end{array}$ & 5 & 11,1 & $\begin{array}{l}\text { Tympanometry } \\
\text { every } 3 \text { months } \\
\text { for } 2 \text { to } 4 \text { years. }\end{array}$ & $\begin{array}{l}\text { OME } \\
\text { predominantly } \\
\text { unilateral } \\
\text { (at least } 5 \\
\text { episodes in } 9 \\
\text { evaluations). }\end{array}$ & MLD & $\begin{array}{l}\text { Binaural } \\
\text { interaction }\end{array}$ \\
\hline $\begin{array}{c}\text { Hogan \& } \\
\text { Moore [3] }\end{array}$ & UK & $\begin{array}{c}\text { Correlate the history } \\
\text { of OME with binaural } \\
\text { hearing in children } \\
\text { with the status of the } \\
\text { middle ear documented } \\
\text { prospectively. }\end{array}$ & 31 & 6,7 & $\begin{array}{l}\text { Otoscopy and } \\
\text { tympanometry } \\
\text { every month in } \\
\text { the first } 5 \text { years } \\
\text { of life. }\end{array}$ & $\begin{array}{c}\text { Type B } \\
\text { tympanogram } \\
\text { on either ear. }\end{array}$ & MLD & $\begin{array}{l}\text { Binaural } \\
\text { interaction }\end{array}$ \\
\hline $\begin{array}{l}\text { Hartley \& } \\
\text { Moore [4] }\end{array}$ & UK & $\begin{array}{l}\text { Investigate the residual } \\
\text { effects of OME in } \\
\text { auditory perception in } \\
\text { school age. }\end{array}$ & 42 & 8,2 & $\begin{array}{l}\text { Tympanometry } \\
\text { every month in } \\
\text { the first } 5 \text { years } \\
\text { of life }\end{array}$ & $\begin{array}{l}\text { Type B } \\
\text { tympanogram } \\
\text { on either ear } \\
\text { (at least } 34 \% \text { of } \\
\text { evaluations) }\end{array}$ & CRM & $\begin{array}{l}\text { Temporal } \\
\text { resolution. }\end{array}$ \\
\hline $\begin{array}{c}\text { Gravel et } \\
\text { al.[6] }\end{array}$ & United States & $\begin{array}{l}\text { Analyze peripheral } \\
\text { and central auditory } \\
\text { processes in a group of } \\
\text { children aged } 8 \text { years, } \\
\text { whose middle ear } \\
\text { function and auditory } \\
\text { acuity were documented } \\
\text { prospectively. }\end{array}$ & $\begin{array}{l}73 \\
\text { (cohort } \\
1 \text { ) } \\
59 \\
\text { (cohort } \\
\text { 2) }\end{array}$ & $\begin{array}{l}8,2(\text { cohort } 1) \\
8,1(\text { cohort } 2)\end{array}$ & $\begin{array}{c}\text { Cohort } 1= \\
\text { Otoscopy every } \\
3 \text { months for } 7 \\
\text { to } 39 \text { mounths. } \\
\text { Cohort } 2= \\
\text { Tympanometry } \\
\text { every } 3 \text { months } \\
\text { for } 7 \text { to } 39 \\
\text { months. }\end{array}$ & $\begin{array}{c}\text { Cohort } 1= \\
\text { Presence of } \\
\text { effusion in the } \\
\text { middle ear } \\
\text { Cohort 2= Type } \\
\text { B tympanogram }\end{array}$ & $\begin{array}{l}- \text { MLD } \\
\text { - AVL } \\
\text { - PSI }\end{array}$ & $\begin{array}{l}\text { - Binaural } \\
\text { interaction; } \\
\text { - Sound } \\
\text { localization; } \\
\text { - Auditory } \\
\text { figure- } \\
\text { ground. }\end{array}$ \\
\hline $\begin{array}{l}\text { Zumach et } \\
\text { al. [5] }\end{array}$ & Netherlands & $\begin{array}{l}\text { The evaluation of the } \\
\text { history of early OME and } \\
\text { its associated hearing } \\
\text { loss has long-term } \\
\text { effects on auditory } \\
\text { perception. }\end{array}$ & 55 & 7,2 & $\begin{array}{l}\text { Otoscopy, } \\
\text { tympanometry } \\
\text { and audiometry } \\
\text { every } 3 \text { months } \\
\text { for } 0 \text { to } 24 \\
\text { months. }\end{array}$ & $\begin{array}{l}\text { Presence of } \\
\text { effusion in the } \\
\text { middle ear } \\
\text { and type B } \\
\text { tympanogram. }\end{array}$ & SPIN test & $\begin{array}{l}\text { Auditory } \\
\text { figure- } \\
\text { ground. }\end{array}$ \\
\hline
\end{tabular}




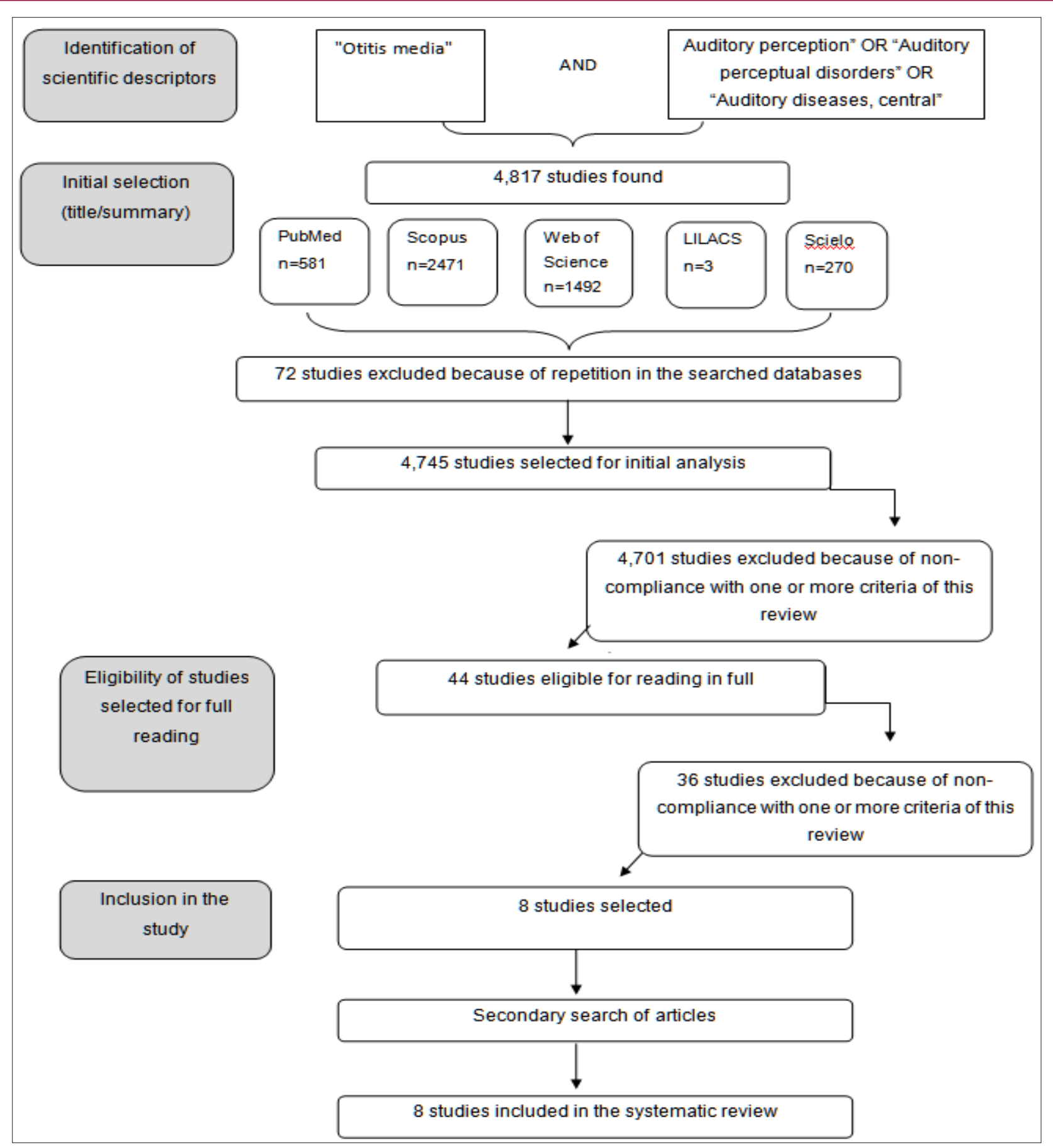

Figure 1: Diagram of the search strategy.

\section{Discussion}

This study was conducted to elucidate the likely changes in the CAP in children and adolescents with a history of early OME documented prospectively. The auditory figure-ground ability is usually affected in children with a history of early OME documented prospectively $[5,15,19]$. Furthermore, the analysis of the ages at follow-up indicated that the changes in the auditory figure-ground persisted even in cases in which the OME was documented only in the first year of life 15. Other studies extended the follow-up to the first 2 years of life 5, and between 2 and 4 years of life [19]. There- fore, it is possible to infer that early OME is a risk factor for changes in the auditory figure-ground even in cases in which the episodes are limited to the first year of life. On the other hand, the three studies that evaluated binaural interaction did not identify changes $[6,10,20]$. Regarding temporal resolution, the results demonstrated in the selected study [4] presented evidence of recovery of this ability after hearing normalization. For other auditory abilities that compose the CAP, no data were found in the studies selected for this review. This review included only prospective studies because of the need for adequate documentation of episodes of early OME for the validation of relevant scientific evidence. 
The discussion held in this study allowed the clarification of the pre-established guiding questions. With regard to the presence of a correlation between hearing deprivation caused by early OME and likely changes in the CAP of children and adolescents, it can be inferred that this correlation occurs to some extent. For CAP abilities that are considered susceptible to early OME, it is possible to infer that the auditory figure-ground ability is considered susceptible because the changes were consistently observed in different studies with a high level of scientific evidence $[5,15,19]$. Therefore, the auditory figure-ground ability is negatively affected by a history of early OME [15].

It should be noted that the speech-in-noise perception might have negative consequences in everyday situations and might limit communication in adverse listening situations [5]. Therefore, interventions are essential in these children considering the significant impact of this ability in the social environment, especially in schools, when the ability in competitive speech is necessary for children to acquire a primary message and ignore concurrent messages, which are potentially distorted [15]. Moreover, the association between age at the first episode and the score in the noise speech test [5] should be a warning sign to clinicians of cases of early OME.

\section{Conclusion}

Finally, the results presented in this study demonstrate that the fluctuating nature of OME may strongly compromise the normal pattern of hearing development, at least with respect to the figure-ground ability. Therefore, it is important to emphasize the need for referral of children diagnosed with early OME to medical intervention and therapy because this condition is treatable.

\section{References}

1. Bluestone CD, Gates GA, Klein JO (2002) Definitions, terminology, and classification of otitis media. Ann Otol Rhinol Laryngol 111: 8-18.

2. Saffer M, Miura MS (2011) Otite media com efusao. In: Caldas Neto S, Mello Junior JF, Martins RHG, Costa SS. Tratado de otorrinolaringologia e cirurgia cervicofacial 2: 84-98.

3. Hogan SCM, Moore DR (2003) Impaired binaural hearing in children produced by a threshold level of middle ear disease. Journal of the Association for Research in Otolaryngology (JARO) 4:123-129.

4. Hartley DEH, Moore DR (2005) Effects of otitis media with effusion on auditory temporal resolution. International Journal of Pediatric Otorhinolaryngology 69: 757-769.

5. Zumach A, Gerrits E, Chenault MN, Anteunis LJC (2009) Otitis media and speech-in-noise recognition in school-aged children. Audiol Neurotol 14: 121-129.

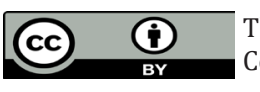

This work is licensed under Creative Commons Attribution 4.0 License

Submission Link: https://biomedres.us/submit-manuscript.php
6. Gravel JS, Roberts JE, Roush J, et al. (2006) Early otitis media with effusion, hearing loss, and auditory process at school age. Ear \& Hearing 27(4): 353-368.

7. Eisen NH (1962) Some effects of early sensory deprivation on later behavior: the quodam hadr-of-hearing child. Journal of Abnormal and Social Psychology 65(5): 338-342.

8. Welsh LW, Welsh JJ, Healy MP (1983) Effect of sound deprivation on central hearing. Laryngoscope 93: 1569-1575.

9. Hogan SCM, Meyer SE, Moore DR (1996) Binaural unmasking returns to normal in teenagers who had otitis media in infancy. Audiol Neurootol 1: 104-111.

10. Stollman MHP, Snik AFM, Schilder AGM, Broek PVD (1996) Measures of binaural hearing in children with a history of asymmetric otitis media with effusion. Audiol Neurotol 1: 175-185.

11. Machado MS (2002) Reconhecimento de sentencas no silencio e no ruido em escolares com e sem historico de otite media recorrente [dissertation]. Santa Maria: Universidade Federal de Santa Maria 2002: 84.

12. Borges LR, Paschoal JR, Colella-Santos MF (2013) (Central) Auditory processing: the impact of otitis media. Clinics 68(7): 954-959.

13. Khavarghazalani B, Farahani F, Emadi M, Dastgerdi ZH (2016) Auditory processing abiities in children with chronic otitis media with effusion. Acta Oto-Laryngologica 136 (5): 456-459.

14. Niclasen J, Obel C, Homoe P, A Korvel-Hanquistd, J Dammeyera (2016) Associations between otitis media and child behavioural and learning difficulties: results from a Danish cohort. International Journal of Pediatric Otorhinolaryngology 84: 12-20.

15. Gravel JS, Wallace IF (1992) Listening and language at 4 years of age: effects of early otitis media. Journal of Speech and Hearing Research 35: 588-595.

16. Maruthy S, Mannarukrishnaiah J (2008) Effect of early onset otitis media on brainstem and cortical auditory processing. Behavioral and Brain Functions 4: 17.

17. Moher D, Liberati A, Tetzlaff J, Altman DG (2009) The PRISMA Group. Preferred Reporting Items for Systematic Reviews and Meta-Analyses: The PRISMA Statement. Plos Medicine 6(7): e1000097.

18. Oxford Centre for Evidence-Based Medicine (OCEBM) (2011) The Oxford 2011 Levels of Evidence. Table of Evidence Working Group.

19. Schilder AGM, Snick AFM, Straatman H, Broek VD (1994) The effect of otitis media with effusion at preschool age on some aspects of auditory perception at school age. Ear \& Hearing 15: 224-231.

20. Hutchings ME, Meyer SE, Moore DR (1992) Binaural masking level diferences in infants with and without otitis media with effusion. Hearing Research 63: 71-78.

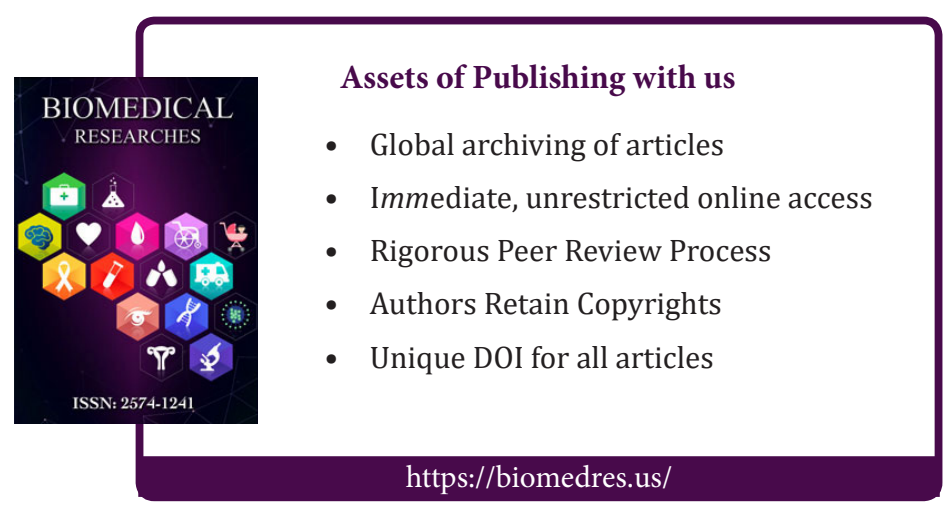

